\title{
Idrar Sitolojisi Günümüzde Mesane Kanserinin Tanı ve Takibinde Gereken Değeri Buluyor mu?
}

\section{Does Urinary Cytology Find the Value in the Detection and Follow-up of Urinary Bladder Cancer?}

\author{
Dr. Kutsal Yörükoğlu \\ Dokuz Eylül Üniversitesi Tıp Fakültesi, Patoloji Anabilim Dalı, Izmir, Türkiye
}

\section{Özet}

Mesane tümörü taramasında ve tümör tanılı olgularda sistoskopi sıklığını azaltmak için idrar sitolojisi ve idrarda tümör belirteçlerinin yeri tartışılmaktadır. Bu derleme makalesinde bu konuda geldiğimiz nokta tartışımaktadır. İdrar sitolojisi ve tümör belirteçlerinin pozitif dediği ancak sistoskopinin negatif olduğu durumlar, tarama yönteminin yanlış pozitifi olarak değerlendirilmişken, son çalışmalarda bu olgularda erken dönemde nükslerin olduğu saptanmıştır. Sistoskopinin yetersiz olduğu durumlar tanımlanmış, negatif sistoskopilerin önemli bir kısmında floresan sistoskopinin pozitif olabildiği gösterilmiştir. Literatürde verilen idrar sitolojisi ve idrarda tümör belirteçlerinin duyarlılık ve özgüllük değerlerinin geniş bir ölçekte dağılmasının, değerlendirme farklııklarından kaynaklandığı vurgulanmaktadır. Şu anda ki verilere göre, idrar sitolojisinin duyarlılığı düşük ama özgüllüğü yüksektir. Buna karşılık, idrarda bakılan tümör belirteçlerinin duyarlıı̆ı yüksektir. Özellikle düşük dereceli tümörleri tanımada ve nüksü erken öngörmede etkin olduğuna yönelik bulgular gözlenmektedir. Hematürili olguların taranmasında, tümör takip olgularında yüksek dereceli nükslerin ve karsinoma in situnun belirlenmesinde idrar sitolojisi hala sistoskopi ile birlikte değerini korumaktadır. Ayrıca, mesane tümörlü olguların üst üriner sistemlerinin taranmasında ve üreter tümörlerinde standart yöntem olarak kullanılması gerekmektedir. Mesane tümörlü olguların takibinde idrar sitolojisine bir tümör belirteçinin eklenmesi, düşük dereceli nükslerin tanınmasına katkı sağlayabilir ve sistoskopi sıklığını azaltabilir. (Üroonkoloji Bülteni 2014;13:109-112)

Anahtar Kelimeler: Mesane kanseri, sistoskopi, idrar, sitoloji, tümör belirteci

\begin{abstract}
Summary
The role of Urine cytology and urine tumor markers in the diagnosis and screening for urinary bladder tumors and in decreasing the frequecy of cystoscopic examinations in bladder cancer patients has been argued. In this review, the recent status of urine cytology and urine tumor markers is assesed. High early recurrence rate has been noted in the cases with positive urine cytology or urine tumor markers but negative cystoscopy. Cystoscopy has been defined to be insufficient in certain conditions in which flourescence cystoscopy was positive in a majority of cases with negative conventional cystoscopy. The wide range in variation of sensitivity and specificity values of urine cytology and urine tumor markers in the literature may be the result of the differences in study designs. Sensitivity of urine cytology is low, but specificity is high. On the other hand, sensitivity of urine tumor markers is high and may be important in detection of recurrences and low-grade tumors. Value of urine cytology together with cystoscopy is still important in screening patients with hematuria, and the diagnosis of high grade tumors and carcinoma in situ in the surveillance of bladder cancer patients. In addition, urine cytology should be routinely used in patients with bladder tumor as well as those with ureteral tumor for screening of upper urinary system. In the surveillance of bladder tumor patients, use of a urine tumor marker with urine cytology may help to diagnose low-grade tumor recurrences and decrease the frequency of cystoscopic examinations. (Bulletin of Urooncology 2014;13:109-112)
\end{abstract}

Key Words: Bladder cancer, cystoscopy, urine, cytology, marker 


\section{Giriş}

İdrar sitolojisi 1945'de Papanicolaou ve Marshall tarafından küçük bir seride yayınlanmıştır (1). Bu dönemde tanıda ki yetersizliği nedeni ile değeri sorgulanmıştır (2). Yeterliliğinin tümörün derecesi ile ilişkili olduğu ve yanlış negatiflerin çoğunun düşük dereceli tümörler olduğu gözlenmiştir $(3,4)$. Bazı otörler, düşük dereceli papiller ürotelyal tümörlerin idrar sitolojisi ile tanınamayacağını belirtirler $(5,6)$. Günümüzde idrar sitolojisi endikasyonları; yüksek riskli popülasyonlarda mesane kanseri taraması, ürotelyal karsinomlu hastaların takibinde nüksü belirleme ve üst üriner sistemin taranması, hematürili ve semptomatik hastaların değerlendirilmesi şeklinde özetlenebilir $(7,8)$.

Ürotelyal karsinomların büyük çoğunluğu kasa invaze olmayan tümörlerdir. Bu olgular, kanser tedavisinde maliyeti en yüksek olan grubu oluşturmaktadır (9) ve tanı ve takiplerinde altın standart sistoskopidir (10). Yüksek riskli olgularda ayrıca üst üriner sistem taraması, sistoskopiye eklenmektedir (10). Bu invaziv tedavi ve takip yönteminin, hastaları rahatsız edici bir yöntem olması yanında enfeksiyon gibi morbid etkileri de azımsanmayacak oranlardadır. İdrar sitolojisinin sistoskopinin yerini alması beklenmiştir. İdrar sitolojisinin yanlış pozitif oranı çok azdır ve dolayısı ile özgüllüğü yüksektir. Buna karşılık duyarlılığı, düşük dereceli tümörleri tanımada ki yetersizliğini yansıtır şekilde düşüktür $(6,7,8)$. Bu nedenle de sistoskopinin yerini alamamıştır. Bu açığı kapatmak için bugüne kadar idrarda tümör belirteçleri önemli araştırma konusu olmuştur $(11,12)$. Bunların içerisinde Urovysion, BTA stat, NMP22 ve uCyt+/Immunocyt, U.S. Food and Drug Administration (FDA) tarafından onaylanmıştır.

İdrar sitolojisinde DNA ploidisi tanıya destek olabilir. Yüksek dereceli tümörlerde ve karsinoma in-situda anöploidi, düşük dereceli tümörlerde ise diploidi gözlenmektedir. Yüksek dereceli tümörlerin tanısı kolaydır ancak kuşkulu idrar sitolojisi tanılarında DNA ploidisi ile tanıya gidilebilir (13). Tanıya yardımcı olması yanı sıra, tümör olgularında DNA ploidisinin bağımsız prognostik gösterge olduğu belirtilmektedir. Şemsiye hücreleri, Polyoma virus enfeksiyonu hücrelerinde DNA ploidisi yanlış pozitif sonuç verebilmektedir. Bu nedenle akım sitometrisi yerine görüntü analizi veya lazer tarama sitometrisinin tercih edilmesi, şemsiye hücrelerinin görülerek analizden çıkartılması tercih edilmelidir $(14,15)$.

Ürotelyal karsinomların gelişiminde 9. kromozom kayıpları, ileri dönemlerinde ise 3., 4., 8., 11., 13., 17., 18. kromozom kayıpları rol oynamaktadır. Kromozom anomalileri floresan in-situ hibridizasyonu (FISH) ile gösterilebilmektedir. Urovysion (Abbott), 3., 7., 9. ve 17. kromozomları değerlendiren FISH yöntemidir. Üçüncü, 7., 17. kromozom polizomisi veya 9p21 kaybı değerlendirilmektedir. Tümör tanılı olguların takibinde özgüllüğü düşüktür (\%70) ve idrar sitolojisine göre duyarlılığı da daha düşük olarak bildirilmektedir (16). Sadece spot idrar için FDA onayı bulunmaktadır ama barbutaj ve mesane yıkama sıvılarında da çalışılabilmektedir (8). Bir başka avantajı da BCG gibi intravezikal tedavilerden etkilenmemesidir. Pahalı olması nedeni ile idrar sitolojisi ile Urovysion arasında uyumsuzluk olduğunda idrar sitolojisi ile takibin tercih edilmesi yeterli olacaktır.

BTA Stat (Alidex Inc.), idrarda kompleman faktör H-ilişkili protein analizine dayalıdır. Muayenehane koşullarında uygulanabilmesi en önemli avantajlı yönüdür. Duyarlılığı \%17-\%89 arasında bildirilmektedir (17). Özgüllüğü ise idrar sitolojisinden daha düşüktür $(11,16)$. Sadece nüks tümörlerde, idrar sitolojisinin duyarlılığını arttırmak için sitolojiye ek olarak kullanılması önerilmektedir.

NMP-22 (Matritech), hücre replikasyonu ile ilişkili bir nükleer matriks proteinidir. Normal hücrelerde NMP-22 düzeyi düşükken, mesane kanseri hücrelerinde 25 kat artma göstermektedir. Kantitatif ELISA testi ile iki farklı epitopu değerlendirilmektedir. Duyarlılığı \%50-\%70, özgüllüğü \%60-\%90 düzeyindedir (18). Olguların önemli bir bölümünde hematüri, enflamasyon gibi nedenler yanlış pozitif sonuçlara yol açmaktadır $(11,16)$. Hem BTA Stat, hem de NMP-22'nin düşük dereceli tümörlerde yanlış negatif sonuçlarının çokluğu, kullanımlarını kısıtlamaktadır. uCyt+/Immunocyt testi (Diagnocure Inc.), üç monoklonal antikora dayalı floresan bir yöntemdir. Müsin benzeri antijenlere yönelik 2 antikor ve karsinoembryonik antijene yönelik bir antikor içermektedir (19). Oldukça zahmetli bir testtir ve değerlendirebilmek için eğitim gerektirmektedir. Ancak, geniş serilerde ki sonuçlar, düşük dereceli tümörlerde oldukça duyarlı (\%53-\%100) olduğunu, yanlış pozitiflerin erken dönem nüks ile ilişkili olduğunu göstermektedir $(17,20,21)$.

Polimeraz zincir reaksiyonu ile mikrosatellit analizi de bir başka tümör belirteci olarak yer almaktadır. Mesane kanserinde birçok kromozom noktasında heterozigozite kaybı (LOH) saptanmaktadır. Özgüllük ve duyarlılığı için farklı değerler verilmekle birlikte, nüksü sistoksopiden önce öngörmede başarılı bulunmaktadır $(16,22)$.

Aslında hematüri de bir idrar belirtecidir. Mesane kanseri taraması için oldukça önemlidir (23). Hematüri taramasının; kasa invaze olmadan mesane kanserinin tanınmasını sağlayarak mortalitesini düşürebileceği belirtilmektedir (16). Ancak, hematüri ile geniş ölçekte tarama, özgüllüğü çok düşük olduğu için olanaksız gözükmektedir (16). Bu nedenle de, hematüri ile gelen olgularda idrar sitolojisi ve diğer tümör belirteçleri yine ön plana çıkmaktadır.

Hematüri veya diğer bulgular ile gelen mesane kanseri düşünülen olgularda, idrar sitolojisi dışındaki tümör belirteçlerinin yeri sınırlı gözükmektedir. Bu olgularda hala sistoskopi ve histopatolojik değerlendirme altın standart olarak durmaktadır (24). İdrar sitolojisi ve tümör belirteçleri tanıya yardımcı olmak, makroskopik izlenemeyen karsinoma in-situyu yakalamak ve üst üriner sistem taraması amaçlı yapılmaktadır. Özgüllüğü yüksek bir tümör belirteci, gereksiz girişimsel işlemlerin engellenmesi için önemlidir. Tanı konmuş hastaların takibinde ise idrar sitolojisi yüksek dereceli tümörler ve karsinoma in-situ için duyarlılık ve özgüllüğü yüksek bir test olarak öne çıkmaktadır. Tümör belirteçlerinin duyarlılı̆ı daha yüksek ama özgüllüğü daha düşüktür (16).

Üst üriner sistem tümörlerinde, üreteroskopik biyopsiler küçük olduğu için olguların yaklaşık dörtte birinde doku tanısı konamamaktadır (25). Bu nedenle selektif üreter idrarı veya fırçalama materyali incelemesinin rutin yapılması önem kazanmaktadır. Üst üriner sistem tümörlerinde idrar sitolojisinin yeterliliği \%78 olarak bildirilmektedir (26). Biyopsi ile karşılaştırıldığında, üst üriner sistem idrar sitolojisinin duyarlılı̆ı \%95, özgüllüğü \%87 gibi tatmin edici düzeylerdedir (27). Taş ve enfeksiyon gibi reaktif süreçler yanlış tanılara neden olabilmektedir, bu nedenle klinik bilgiler ile birlikte değerlendirilmesi önemlidir. 
Mesane kanseri taramasında en iyi yöntem hala idrar sitolojisi gibi gözükmektedir. Özgüllüğü oldukça iyi olan idrar sitolojisinde yanlış pozitif oranı oldukça düşüktür. Buna karşılık, düşük dereceli papiller tümörleri yakalamada ki başarısızığına bağlı olarak duyarlıığı düşük kalmaktadır. Düşük dereceli noninvaziv tümörlerde nüks oranı yüksek ama progresyon oranı göreceli düşüktür. Bu olgularda takipte önemli olan yüksek dereceli tümörlerin ve karsinoma in-situnun erken yakalanmasıdır $(28,29,30)$. Ayrıca, kasa invaze olmayan düşük dereceli mesane tümörlerinde agresif nükslerin öngörülmesi de önemlidir (31). Bu nedenle yüksek dereceli tümörlerde duyarlılıktan çok, özgüllük önem kazanmakta, en iyi yaklaşım idrar sitolojisi ve sistoskopik değerlendirme olarak yer almaya devam etmektedir $(16,32)$. Düşük dereceli tümörlerde ise sistoskopilerin sıklığı, uygun bir idrar testi ile azaltılabilir. Bu durumda hem duyarlılık, hem de özgüllüğün iyi olması gerekmektedir. Bu olgularda idrar sitolojisinin duyarlıı̆ı düşük kalmaktadır $(16,18)$. Çalışılmış olan ve burada bazılarına değinilmiş olan idrar tümör belirteçlerinin hepsinin öne çıkan ve yetersiz kaldığı durumlar vardır. En iyi yöntemi belirlemek olanaksız gözükmektedir. Ancak ek bir yöntem kullanılması ve bunun sonucunun ürolog tarafından bilinmesi, nüksleri yakalamada sistoskopinin başarısını arttırmaktadır (33).

Urovysion, mikrosatellit instabilitesi ve uCyt+/Immunocyt testlerinde yanlış pozitiflikler, altın standart olarak sistoskopi sonucu değerlendirilerek karar verilen durumlardır. Bu olgularda, sistoskopi negatif olmakla birlikte erken dönemde nüks saptanabilmektedir (16). Sistoskopi rutin yapıldığında atlanan bazı olguların floresan ışık sistoskopisi ile yakalanabildiği de vurgulanmaktadır (34). Bu yöntemin maliyeti arttırdığı ve karşı yönde yayınlar olduğu unutulmamalıdır $(35,36,37,38,39,40)$. İdrar sitolojisinin yeterliliğinin de değerlendiricinin deneyimine bağlı olduğu unutulmamalıdır $(41,42)$. Literatürde yer alan duyarılıı ve özgüllük rakamlarının, patoloğun deneyiminden ve hatta sitolojinin laboratuvar işlemlerinin farklılı̆ından etkileniyor olabileceği belirtilmektedir (43).

\section{Sonuç}

İdeal bir tümör belirteci sadece tümörü göstermeli, başka hastalıklarda/durumlarda pozitif olmamalı ve tümörlerin hepsini gösterebilmelidir. Yani, duyarlılık ve özgüllüğü \%100 olmalıdır. Böyle bir ideal belirteçe hiçbir tümör veya hastalık için sahip değiliz. Tümör belirteçlerinden en iyisi PSA olarak kabul edilmektedir. PSA'nın eksi yönlerini burada tartışmaya gerek yok. İrar sitolojisi de ideal tümör belirteci veya tarama yöntemi olmaktan uzaktır. Ama, mesane tümörü ve karsinoma in-situ için elimizde \%100 doğrulukta bir yöntem de bulunmamaktadır. Yukarıda söz edilenler dışında çalışılmış birçok test bulunmakta ve yenileri tanımlanmaya devam edilmektedir (xylinas). Hematürili olgularda mesane tümörü taramasında, mesane tümörü tanılı olgularda yüksek dereceli nüksü ve karsinoma in-situyu yakalamada idrar sitolojisi hala en iyi yöntem olarak durmaktadır. Bugüne kadar tüm araştırmalarda veriler altın standarta göre değerlendirilerek bir takım duyarlılık ve özgüllük rakamlarına ulaşıımışır. Yukarıda belirtilen gerekçeler nedeni ile bu rakamlar bu testlerin gerçek yeterliliğini vermiyor olabilir. Hem idrar sitolojisini, hem de bu tümör belirteçlerinin yeni başlayan bir tümörü veya karsinoma in-situyu altın standart yöntemimiz olan sistoskopiden daha iyi belirlediği, sistoskopinin uygulayıcı bağımlı olduğu unutulmamalıdır. Idrar sitolojisine Urovysion, uCyt+/Immunocyt, mikrosatellit instabilitesi gibi tümör belirteçlerinden biri eklenerek sistoskopi sıklığı azaltılabilir.

\section{Kaynaklar}

1. Papanicolaou GN, Marshall VF. Urine sediment smears as a diagnostic procedure in cancers of the urinary tract. Science 1945;101:519-521.

2. Foot NC, Papanicolaou GN, Holmquist ND, Seybolt JF. Exfoliative cytology of urinary sediments; a review of 2,829 cases. Cancer 1958;11:127-137.

3. Umiker W, Lapides J, Sourenne R. Exfoliative cytology of papillomas and intra-epithelial carcinomas of the urinary bladder. Acta Cytol $1962 ; 6: 255-266$.

4. de Voogt HJ, Wielenga G. Clinical aspects of urinary cytology. Acta Cytol. 1972;16:349-351.

5. Esposti PL, Zajicek J Grading of transitional cell neoplasms of the urinary bladder from smears of bladder washings. A critical review of 326 tumors. Acta Cytol 1972; 16:529-537.

6. Koss L, Melamed M. Koss' diagnostic cytology and its histopathologic bases. 5nd editon.Philadelphia PA: Lippincott Williams\&Wilkins; 2005:38-46.

7. Bostwick DG, Cheng L. Urine Cytology. In: David G. Bostwick DG, Cheng L (Eds). Urologic Surgical Pathology, 3rd Ed, Saunders; 2014;318-349.

8. Barkan GA, Wojcik EM. Genitourinary Cytopathology (Kidney and Urinary Tract).Cancer Treatment and Research 2014;160:149-183.

9. Botteman MF, Pashos $\mathrm{CL}$, Redaelli $\mathrm{A}$, et al. The health economics of bladder cancer: a comprehensive review of the published literature. Pharmacoeconomics 2003;21:1315-1330.

10. Babjuk M, Oosterlinck W, Sylvester R, et al. EAU guidelines on non-muscle-invasive urothelial carcinoma of the bladder. Eur Urol 2008;54:303-314.

11. Vrooman OP, Witjes JA. Urinary markers in bladder cancer. Eur Urol 2008;53:909-916.

12. Konety $B$, Lotan $Y$. Urothelial bladder cancer: biomarkers for detection and screening. BJU Int 2008;102: 1234-1241.

13. Badalament RA, Kimmel M, Gay $H$, et al. The sensitivity of flow cytometry compared with conventional cytology in the detection of superficial bladder carcinoma. Cancer 1987;59:2078-2085.

14. Bakhos R, Shankey TV, Flanigan RC, et al. Comparative analysis of DNA flow cytometry and cytology of bladder washings: review of discordant cases. Diagn Cytopathol 2000;22: 65-69.

15. Wojcik EM, Brownlie RJ, Bassler T], et al. Superficial urothelial (umbrella) cells. A potential cause of abnormal DNA ploidy results in urine specimens. Analyt Quant Cytol Histol 2000;22:411-415.

16. van Rhijn BW, van der Poel HG, van der Kwast TH. Urine markers for bladder cancer surveillance.a systematic review. Eur Urol 2005;47:736-748.

17. Tetu B. Diagnosis of urothelial carcinoma from urine. Mod Pathol 2009;22 (Suppl 2):53-59.

18. Grossman HB, Soloway M, Messing E, et al. Surveillance for recurrent bladder cancer using a point-of-care proteomic assay. JAMA 2006;295:299-305.

19. Fradet $Y$, Lockhart C.Performance characteristics of a new monoclonal antibody test for bladder cancer: Immunocyt trade mark. Can J Urol. 1997;4:400-405.

20. Mian C, Maier K, Comploj E, et al. uCyt+/ImmunoCyt in the detection of recurrent urothelial carcinoma: an update on 1991 analyses. Cancer 2006;108:60-65. 
21. Messing EM, Teot $\mathrm{L}$, Korman $\mathrm{H}$, et al. Performance of urine test in patients monitored for recurrence of bladder cancer: a multicenter study in the United States. J Urol 2005;174:1238-1241.

22. van der Aa MN, Zwarthoff EC, Steyerberg EW, et al. Microsatellite analysis of voided-urine samples for surveillance of low-grade nonmuscle-invasive urothelial carcinoma: feasibility and clinical utility in a prospective multicenter study (Cost-Effectiveness of Follow-Up of Urinary Bladder Cancer trial [CEFUB]). Eur Urol 2009;55:659-667.

23. Messing EM, Young TB, Hunt VB, et al. Home screening for hematuria: results of a multiclinic study. J Urol 1992;148:289-292.

24. Brown FM. Urine Cytology. It is still the gold standard for screening? Urol Clin North Am 2000;27:25-37.

25. Tavora F, Fjardo DA, Lee TK, et al. Small endoscopic biopsies of the ureter and renal pelvis: pathologic pitfalls. Am J Surg Pathol 2009;33:1540-1546.

26. Gittes RF. Retrograde brushing and nephroscopy in the diagnosis of upper-tract urothelial cancer. Urol Clin North Am 1984;11: 617-622.

27. Havens MA, Cabay RJ, Mehrotra S, et al. Upper genitourinary tract cytology: more sensitive than surgical biopsy? Cancer Cytopath 2009;117:371-379.

28. van Rhijn BWG, van der Poel HG, van der Kwast TH. Cytology and urinary markers for the diagnosis of bladder cancer. Eur Urol Suppl 2009;8:536-541.

29. Kroft SH, Oyasu R. Urinary bladder cancer: mechanisms of development and progression. Lab Invest 1994;71:158-174.

30. Soloway MS. Do we have a prostate specific antigen for bladder cancer? J Urol 1999;161:447-448.

31. Zhou AG, Owens CL, Cosar EF, Jiang Z. Clinical implications of current developments in genitourinary pathology. Arch Pathol Lab Med 2013l;137:887-893.

32. Lotan $Y$, Roehrborn CG. Sensitivity and specificity of commonly available bladder tumor markers versus cytology: results of a comprehensive literature review and meta-analyses. Urology 2003;61:109-118.
33. van der Aa MN, Steyerberg EW, Bangma C, et al. Cystoscopy revisited as the gold standard for detecting bladder cancer recurrence: diagnostic review bias in the randomized, prospective CEFUB trial. I Urol 2010;183:76-80.

34. Karl A, Tritschler S, Stanislaus P, et al. Positive urine cytology but negative white-light cystoscopy: an indication for fluorescence cystoscopy? BJU Int 2009;103:484-487.

35. Horstmann M, Banek S, Gakis G, et al. Prospective evaluation of fluorescence-guided cystoscopy to detect bladder cancer in a highrisk population: results from the UroScreen-Study. Springerplus 2014;3:24.

36. Xylinas $E$, Kluth LA, Rieken $M$, et al. Urine markers for detection and surveillance of bladder cancer. Urol Oncol 2014;32:222-229.

37. Bryan RT, Shimwell NJ, Wei W, et al. Urinary EpCAM in urothelial bladder cancer patients: characterisation and evaluation of biomarker potential. Br J Cancer 2014;110:679-685.

38. de Martino M, Shariat SF, Hofbauer SL, et al. Aurora A Kinase as a diagnostic urinary marker for urothelial bladder cancer. World J Urol 2014.

39. Shabayek MI, Sayed OM, Attaia HA, et al. Diagnostic Evaluation of Urinary Angiogenin (ANG) and Clusterin (CLU) as Biomarker for Bladder Cancer. Pathol Oncol Res 2014.

40. Su SF, de Castro Abreu AL, Chihara Y, et al. A panel of three markers hyper- and hypomethylated in urine sediments accurately predicts bladder cancer recurrence. Clin Cancer Res 2014;20:1978-1989.

41. Raitanen MP, Aine R, Rintala E, et al. Differences between local and review urinary cytology in diagnosis of bladder cancer. An interobserver multicenter analysis. Eur Urol 2002;41:284-289.

42. Ataç G, Aktaş $S$, Yörükoğlu K, ve ark. Idrar sitolojisinde tanısal yeterlilik, sensitivite spesifisite ve yanlış pozitif oranlarımız. Dokuz Eylül Üniversitesi Tıp Fakültesi Dergisi 1999;9:95-99.

43. Schmitz-Dräger BJ, Todenhöfer T, van Rhijn B, et al. Considerations on the use of urine markers in the management of patients with low-/intermediate-risk non-muscle invasive bladder cancer. Urol Oncol 2014:1078-1439. 